\title{
Pembinaan Implementasi E-Filing bagi Pelaku UMKM Kerupuk di Kecamatan Gunung Anyar Kota Surabaya
}

\author{
I Made Laut Mertha Jaya S.E., M.A ${ }^{(1)}$, Mar'a Elthaf Ilahiyah, S.E., M.A ${ }^{(2)}$ \\ (1) STIE Bisnis dan Perbankan Yogyakarta, e-mail: mad.jaya@yahoo.com \\ ${ }^{(2)}$ STIESIA Surabaya, e-mail: mar'aelthafilahiyah@stesia.ac.id ${ }^{2}$
}

\begin{abstract}
Micro, Small and Medium Enterprises (MSMEs) in Indonesia are one of the pillars of the Indonesian economy besides cooperatives. Based on 2011 Gross Domestic Product (GDP) data, MSMEs contribute approximately 57\% of total GDP. However, when compared with the contribution of MSMEs to tax revenues, there is a miss-match where the contribution of MSMEs to tax revenues is very small, which is approximately $0.5 \%$ of total tax revenues. Therefore, it is expected that with this tax service activity through fostering and implementing e-filing for the Kerupuk MSME actors in Gunung Anyar District, Surabaya City is expected to be able to assist in the field of tax management. The method or steps for implementing community service are carried out by providing taxation materials (e-filing), income tax $(P P h)$, and mentoring programs regarding taxation. This dedication activity concludes that there is a need for continuous activity and evaluation periodically after community service activities are carried out, so that the Kerupuk MSME actors in Gunung Anyar Subdistrict, Surabaya City can contribute to the development of MSMEs in East Java. Participants in Kerupuk SMEs in Gunung Anyar Subdistrict, Surabaya City have the ability to prepare and implement their business tax reports properly and correctly and accountably.
\end{abstract}

Keywords: Tax Assistance Program for MSMEs, e-filing, Tax for MSMEs.

\begin{abstract}
Abstrak
Usaha Mikro Kecil Menengah (UMKM) di Indonesia merupakan salah satu soko guru perekonomian Indonesia selain koperasi. Berdasarkan data Produksi Domestik Bruto (PDB) tahun 2011, UMKM mempunyai kontribusi kurang lebih 57\% dari total PDB. Namun demikian, apabila dibandingkan dengan kontribusi UMKM terhadap penerimaan pajak, terdapat miss-match dimana kontribusi UMKM pada penerimaan perpajakan sangat kecil, yaitu kurang lebih $0.5 \%$ dari total penerimaan pajak. Oleh karena itu, diharapkan dengan adanya kegiatan pengabdian perpajakan ini melalui pembinaan dan implementasi $e$ filing bagi para pelaku UMKM Kerupuk di Kecamatan Gunung Anyar, Kota Surabaya diharapkan dapat membantu di bidang pengelolahan pajaknya. Metode atau langkah-langkah pelaksanaan pengabdian masyarakat ini dilakukan dengan cara pemberian materi perpajakan (e-filing), pajak penghasilan $(\mathrm{PPh})$ dan program pendampingan mengenai perpajakan. Kegiatan pengabdian ini menyimpulkan bahwa perlu adanya kesinambungan kegiatan dan evaluasi secara berkala setelah kegiatan pengabdian kepada masyarakat ini dilakukan sehingga para pelaku UMKM Kerupuk di Kecamatan Gunung Anyar, Kota Surabaya dapat berkontribusi dalam pengembangan UMKM di Jawa Timur. Peserta pelaku UMKM Kerupuk di Kecamatan Gunung Anyar, Kota Surabaya memiliki kemampuan dalam menyusun dan mengimplementasikan laporan pajak usahanya secara baik dan benar serta dapat dipertanggungjawabkan.
\end{abstract}

Kata Kunci : Program Pendampingan Perpajakan, e-filing, pajak UMKM 


\section{PENDAHULUAN}

Kewirausahaan melalui Usaha Mikro Kecil Menengah (UMKM) dapat meningkatkan kreatifitas dan kemampuan masyarakat dalam menyalurkan ide dan kreasinya dengan memanfaatkan sumber daya alam yang tersedia (Darwanto, 2013). Usaha Mikro Kecil Menengah (UMKM) di Indonesia merupakan salah satu soko guru perekonomian Indonesia selain koperasi (Hejazziey, 2009). Kontribusi Usaha Mikro Kecil dan Menengah (UMKM) terhadap produk domestik bruto memang mengalami peningkatan dan menggeliat dalam lima tahun terakhir (LAKIP KUKM, 2016). Hal itu disebabkan Kementrian Koperasi dan Usaha Kecil Menengah (UKM) yang memberikan peluang untuk pebisnis kecil berkembang. Kementrian telah mencatat bahwa kontribusi di sektor UMKM meningkat mulai dari 57.84 persen menjadi 60,34 persen. Sektor UMKM juga mampu menyerap tenaga kerja di dalam negeri dari 96,99 menjadi 97,22 persen dalam 5 tahun terakhir (CNN, 2016). Hal itu dapat membantu pertumbuhan ekonomi Indonesia menjadi lebih baik.

Penyerapan tenaga kerja yang cukup meningkat mampu meningkatkan pendapatan masyarakat. Dengan kata lain, UMKM dianggap memiliki peran yang

cukup strategis dalam memerangi kemiskinan dan pengangguran yang ada di Indonesia. Selain itu, kontribusi terbesar dari usaha UMKM adalah industri ekonomi kreatif. Hal ini dapat dilihat dari data pertumbuhan yang cukup positif dengan pertumbuhan hingga 5,6 persen sejak 2010 sampai 2013. UMKM ini juga mampu memberikan sumbangsih terhadap PDB yang tercatat mencapai 7,1 persen dan mampu menyerap 10,7 persen atau sekitar 12 juta total dari tenaga kerja.

Kota Surabaya memiliki banyak potensi usaha yang menjadi sumber pendapatan utama penduduk di sekitarnya, mulai dari industri makanan, industri kerajinan, industri tekstil dan industri agrobisnis yang semuanya dapat berkembang pesat. Untuk mengatasi pengangguran di kota besar, Pemerintah Kota (Pemkot) Surabaya mempercepat pertumbuhan usaha mikro, kecil dan menengah (UMKM). Perkembangan UMKM dapat dilihat dalam setahun terakhir ini, sejak Januari sampai Desember 2017, sudah ada 150 UMKM yang sudah didaftarkan sertifikasi mereknya di Kementerian Hukum dan HAM (Kemenkumham). Jumlah itu ditambah dengan 67 UMKM yang didaftarkan sertifikasi halalnya di 
Lembaga Pengkajian Pangan Dan ObatObatan (LPPOM) MUI. Selain itu, berdasarkan data Produksi Domestik Bruto (PDB) tahun 2011, UMKM mempunyai kontribusi kurang lebih $57 \%$ dari total PDB. Namun demikian, apabila dibandingkan dengan kontribusi UMKM terhadap penerimaan pajak, terdapat missmatch dimana kontribusi UMKM pada penerimaan perpajakan sangat kecil, yaitu kurang lebih $0.5 \%$ dari total penerimaan pajak (Utami dan Zahruddin, 2017). Ketidakimbangan kontribusi UMKM tersebut merupakan suatu indikasi bahwa tingkat ketaatan UMKM dalam memenuhi kewajiban perpajakan masih sangat rendah.

Sebagai upaya untuk mendorong pemenuhan kewajiban perpajakan secara sukarela (voluntary tax compliance) serta mendorong kontribusi penerimaan negara dari UMKM, pemerintah telah menerbitkan Peraturan Pemerintah Nomor 46 Tahun 2013 tentang Pajak Penghasilan atas Penghasilan dari Usaha yang Diterima atau Diperoleh Wajib Pajak yang Memiliki Peredaran Bruto Tertentu (PP 46/2013). Pada Peraturan Pemerintah ini diatur pengenaan Pajak Penghasilan (PPh) yang bersifat final atas penghasilan yang diterima atau diperoleh Wajib Pajak dengan batasan peredaran bruto tertentu.

Kecamatan Gunung Anyar dikenal sebagai sentra kerupuk ikan dan menjadi salah satu icon di Kota Surabaya. Di sepanjang kampung Gunung Anyar Tambak, terlihat sejumlah pengrajin kerupuk, dengan berbagai varian produk yang dihasilkan, antara lain kerupuk udang, kerupuk ikan dan kerupuk kerang dan banyak lainnya. Kerupuk di Kecamatan ini telah banyak dijadikan sebagai salah satu oleh-oleh khas di Surabaya. Hal ini menimbulkan tumbuhnya sektor industri UMKM Kerupuk di Kecamatan ini. Namun, kendala yang dihadapi oleh mayoritas pelaku usaha UMKM Kerupuk di Kecamatan ini adalah sulitnya memahami dan melakukan pelaporan pajak usaha mereka. Bahkan beberapa ada yang belum memiliki NPWP atas usahanya. Oleh karena itu, diharapkan dengan adanya kegiatan pengabdian perpajakan ini melalui pembinaan dan implementasi $e$ filing bagi para pelaku UMKM di Kecamatan Gunung Anyar dapat membantu di bidang pengelolaan pajaknya.

\section{METODE PELAKSANAAN}


Masyarakat yang tinggal di Kecamatan Gunung Anyar merupakan daerah yang hampir dikenal dengan sentra industri UKMnya. Banyak usaha yang mereka jalankan namun pengelolaan keuangannya masih bercampur dengan keuangan rumah tangga dan belum dibukukan. Di daerah tersebut juga belum ada makanan yang dijadikan ciri khas maka pengabdi memberikan pelatihan pengelolaan keuangan meliputi pelatihan pengelolaan keuangan usaha UKMnya serta penyusunan laporan pajaknya.

Metode atau langkah-langkah pelaksanaan pengabdian masyarakat ini berdasarkan permasalahan mitra, yaitu pembinaan dan implementasi $e$-filing bagi para pelaku UMKM sehingga langkahlangkah yang dilakukan pengabdi sebagai berikut:
a. Pelatihan tentang materi perpajakan (e-filing).

Pelatihan ini memberikan gambaran tentang kemudahan di dalam menyusun dan melaporkan pajak UKM melalui e-filing. Diharapkan dengan masyarakat pelaku UKM menggunakan e-filing maka kegiatan mengisi dan mengirim SPT tahunan dapat dilakukan dengan mudah dan efisien. Formulir elektronik pun telah tersedia di layanan pajak online yang akan memandu para pengguna layanan. Selain itu, layanan pajak online juga dapat diakses kapan dan di mana pun sehingga penyampaian SPT dapat dilakukan setiap saat selama 24 jam. Dengan e-filing, tidak perlu lagi dokumen fisik berupa kertas karena semua dokumen akan dikirim dalam bentuk dokumen elektronik.

Gambar 1. Kegiatan pelatihan dengan menggunakan modul materi ringan

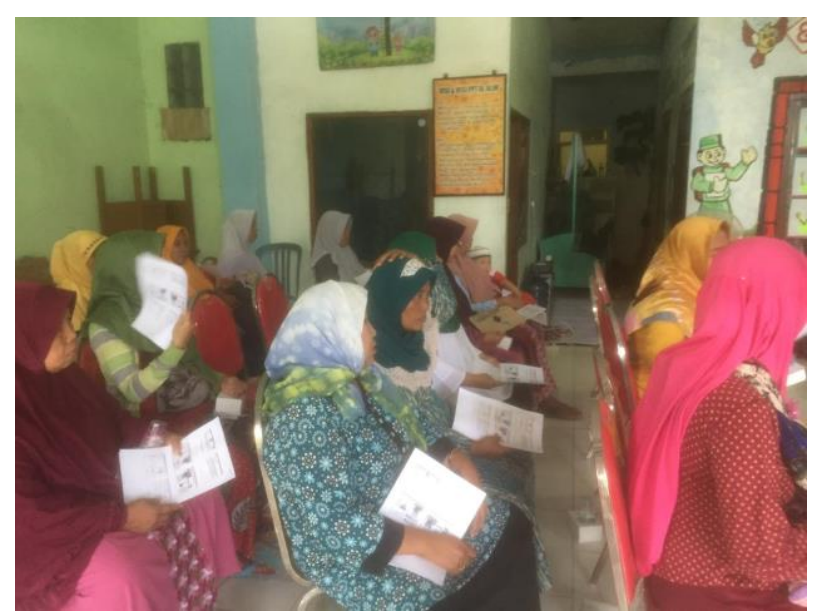


b. Pelatihan tentang pajak penghasilan (PPh)

Materi pelatihan dibagi ke dalam beberapa materi, yaitu $\mathrm{PPh}$ orang pribadi, pajak penghasilan $\mathrm{PPh} 21$, Pasal 23 dan PPh Pasal 4 ayat 2 serta PPh badan. Materi PPh Orang Pribadi membahas tentang :

1. Ketentuan umum perpajakan suami isteri.

2. Mekanisme penghitungan pajak bagi penerima penghasilan lebih dari satu pemberi kerja.

3. Pelaporan melalui $e$-filing.

Sementara itu, untuk materi pajak penghasilan PPh 21, Pasal 23 dan PPh Pasal 4 ayat 2 membahas tentang :

1. Objek PPh 21.

2. Mekanisme penghitungan pajak bagi pegawai tetap, penghitungan THR dan penghitungan pegawai yang berhenti di tengah tahun.

3. Mekanisme pembetulan dan pemindahbukuan.

4. Pelaporan e-SPT melalui $e$ filing.

Untuk materi perpajakan $\mathrm{PPh}$ Badan, sesinya membahas tentang :

1. Pelaporan keuangan UKM sesuai dengan SAK EMKM yang mulai berlaku sejak tanggal 1 Januari 2018.

2. Mekanisme pengisian SPT PPh Badan.

3. Pelaporan SPT PPh Badan melalui $e$-filing.

Gambar 2. Kegiatan pelatihan dengan praktik langsung 


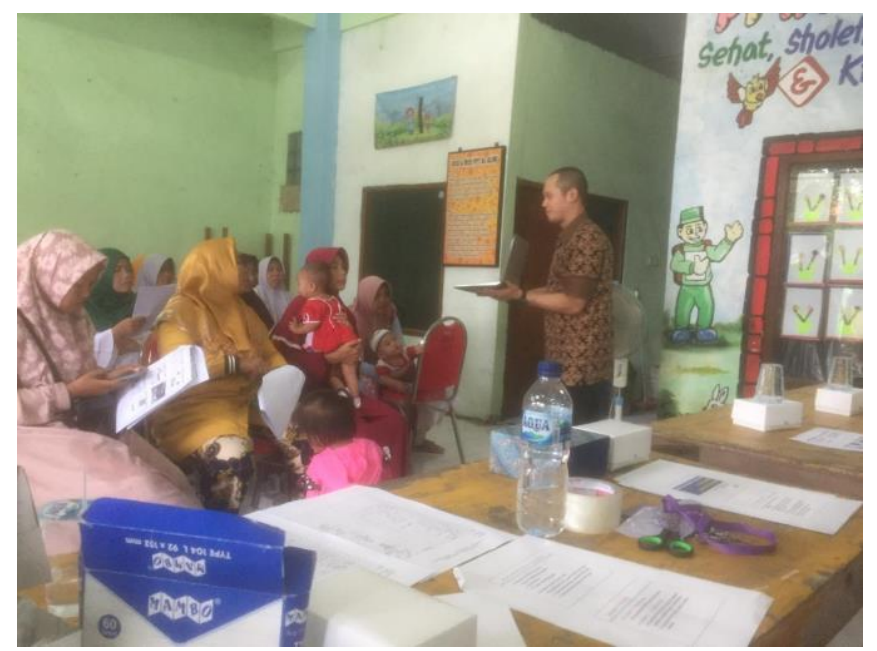

c. Program pendampingan mengenai perpajakan.

Program pendampingan

dilakukan dengan cara:

1. Pendampingan dalam hal penyusunan laporan pajak sesuai SAK EMKM yang mulai berlaku sejak 01 Januari 2018.
2. Pendampingan kepada para pelaku UMKM peserta pelatihan dalam memahami mekanisme pengisian SPT dan pelaporannya menggunakan e-filing (IAI, 2016).

Gambar 3. Kegiatan pelatihan dengan praktik langsung

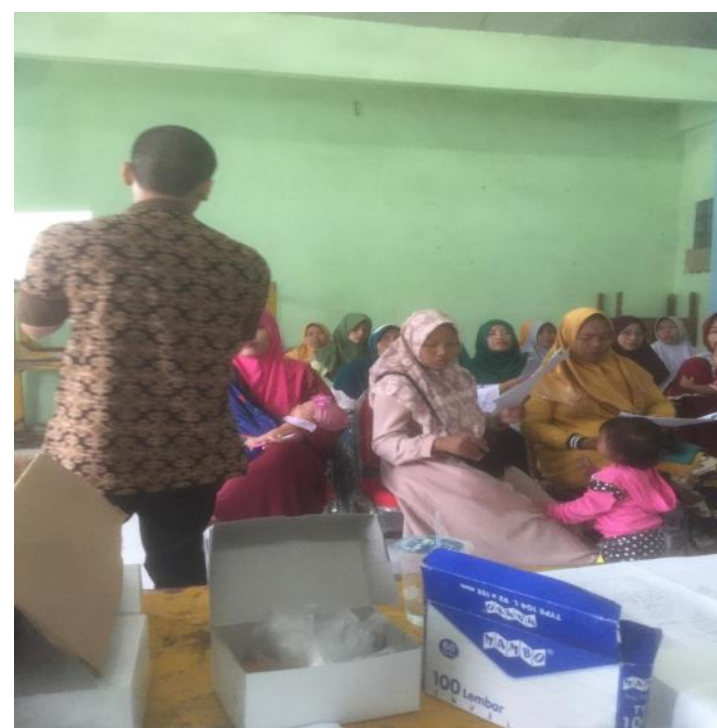

\section{HASIL DAN PEMBAHASAN}


Pengabdian kepada masyarakat adalah suatu kegiatan yang bertujuan membantu masyarakat tertentu dalam beberapa aktivitas (Menristekdikti, 2016). Secara umum program ini dirancang oleh Perguruan Tinggi sesuai dengan Tri Dharma pemenuhan kegiatan kerja dari para dosennya. Selain itu, kegiatan pengabdian ini juga untuk memberikan kontribusi nyata bagi masyarakat, khususnya dalam mengembangkan kesejahteraan dan kemajuan masyarakat Indonesia.

Kegiatan pengabdian kepada masyarakat ini dihadiri sebanyak 20 orang. Para peserta pelaku UMKM Kerupuk yang hadir, diminta mengisi terlebih dahulu daftar hadir yang telah disediakan. Setelah itu, panitia akan membagikan masingmasing konsumsi, alat tulisan modul materi yang akan diberikan kepada pelaku usaha UMKM sebagai pedoman selama pelatihan dan untuk menyusun serta melaporkan laporan pajak mereka (Jaya, Sujarweni, 2019).

Materi disampaikan oleh dosen STIE Bisnis dan Perbankan Yogyakarta, Bapak I Made Laut Mertha Jaya, materi yang diberikan berkaitan dengan beberapa topik, yaitu etika bisnis, pembukuan sederhana, penyusunan laporan keuangan sesuai SAK EMKM, penyusunan laporan perpajakan dan pendampingan pelaporan pajak dengan $e$-filing. Penyampaian materi membutuhkan waktu kurang lebih 150 menit, kemudian dilanjutkan dengan sesi tanya jawab. Setelah tanya jawab selesai, selanjutnya pelaku UMKM dapat mengajukan diri untuk melakukan pendampingan penyusunan dan pelaporan pajaknya.

Selama kegiatan berlangsung, para peserta nampak antusias. Hal ini terlihat dari keaktifan peserta dalam mengajukan pertanyaan. Terdapat beberapa peserta pula yang berminat untuk belajar lebih lanjut mengenai setiap materi yang dipaparkan. Terutama pada sesi materi pembukuan sederhana dan juga perpajakan karena banyak dari pelaku UMKM masih belum terlalu paham. Selanjutnya, dilaksanakan pendampingan secara berkala kepada para pelaku UMKM di Kecamatan Gunung Anyar, Kota Surabaya. Namun, untuk mengukur tingkat keberhasilan program kegiatan pengabdian ini adalah peserta pelaku UMKM langsung dapat menyusun dan melaporkan laporan pajak melalui $e$-filling sesuai dengan transaksi yang terjadi di UMKM di Kecamatan Gunung Anyar, Kota Surabaya.

Kegiatan pengabdian kepada masyarakat yang telah diterapkan melalui pelatihan materi perpajakan (e-filing) ini dapat memberi manfaat kepada khalayak 
luas sehingga selanjutnya pengabdi merekomendasikan beberapa hal, yaitu:

1. Perlu adanya kesinambungan kegiatan dan evaluasi setelah kegiatan pengabdian kepada masyarakat ini dilakukan sehingga para pelaku UMKM di Surabaya dapat berkontribusi dalam pengembangan UMKM di Indonesia.

2. Mengadakan edukasi yang serupa kepada komunitas masyarakat lain yang berbeda.

3. Salah satu yang mengakibatkan pengusaha mudah sekali mengalami kebangkrutan karena sebagian mereka kurang menguasai pengelolaan keuangan bisnisnya. Oleh karena itu, dengan membayar pajak UMKM maka diharapkan pelaku usaha dapat belajar juga untuk mengelola keuangan dari hasil bisnisnya. Bagi pengusaha yang menjalankan Usaha Kecil Menengah (UKM), sekarang tersedia pajak khusus UKM yang

\section{KESIMPULAN}

Berdasarkan kegiatan pengabdian yang telah dilaksanakan maka diperoleh beberapa kesimpulan, di antaranya:

a. Pajak merupakan salah satu alat stabilitas ekonomi dalam berbagai kondisi dan dapat dianggap mengancam suatu keberlangsungan jalannya sedikit ringan pembayarannya dengan membayar $1 \%$ tiap bulan. Otomatis, dengan membayar $1 \%$ dari omzet tiap bulan, mereka juga dapat belajar mengelola keuangan bisnis dengan lebih baik.

4. Keunggulan lain dari membayar pajak adalah bisnis yang dikelola akan terlihat profesional di mata distributor maupun konsumen. Jika pihak UMKM bergelut dalam bisnis di segala bidang maka NPWP (Nomor Pokok Wajib Pajak) adalah salah satu bagian terpenting dalam surat kerja sama kontrak dengan konsumen maupun distributor. Jika tidak ada NPWP maka UMKM, tidak akan terlihat profesional. Dengan mengetahui begitu banyak manfaat yang didapat dari perpajakan bagi UMKM maka perlu untuk dilakukan pembinaan berkala terhadap materi perpajakan bagi pelaku UMKM.

perekonomian negara. Dengan kehadiran pajak, pemerintah memiliki banyak opsi dalam membuat dan menerapkan sebuah kebijakan. Contohnya, sebagian barang-barang impor yang dikenakan pajak tinggi oleh pemerintah, hal ini bertujuan agar 
produksi dalam negeri mampu bersaing di pasaran. Tidak hanya itu, dalam upayanya menjaga nilai tukar rupiah dan menjaganya dari peluang terkena defisit yang terlalu melebar, pemerintah bisa mengenakan PPnBM (Pajak Penjualan atas Barang Mewah) terhadap produkproduk mewah impor. Dengan demikian, jumlah impor barang mewah yang memiliki kontribusi besar terhadap neraca perdagangan akan meredam dan berkurang dengan sendirinya. Dari contoh di atas, dapat disimpulkan bahwa para pengusaha dapat memperoleh keuntungan yang berlipat dengan melakukan tertib pelaporan dan pembayaran pajaknya. Pertama, pengusaha dapat meningkatkan bisnisnya untuk terus maju dan bersaing dengan barang-barang produksi impor. Kedua, pengusaha juga ikut

\section{Saran:}

Beberapa saran yang dapat diajukan untuk kesuksesan pelaksanaan pengabdian selanjutnya, yaitu:

1. Perlu adanya kerjasama secara
berkelanjutan antara perguruan tinggi
dengan organisasi masyarakat lainnya
untuk meningkatkan kesuksesan
kegiatan pengabdian masyarakat dan
memberikan pembelajaran bagi
masyarakat untuk kemajuan

menstabilkan perekonomian negara dan membantu pembangunan perekonomian dengan baik.

b.Perlu adanya kesinambungan kegiatan dan evaluasi secara berkala setelah kegiatan pengabdian kepada masyarakat ini dilakukan, sehingga para pelaku UMKM Kerupuk di Kecamatan Gunung Anyar, Kota Surabaya dapat berkontribusi dalam pengembangan UMKM di Jawa Timur.

c. Peserta pelaku UMKM Kerupuk di Kecamatan Gunung Anyar, Kota Surabaya memiliki kemampuan dalam menyusun dan mengimplementasikan laporan pajak usahanya secara baik dan benar serta dapat dipertanggungjawabkan.

pengetahuan mereka serta sebagai tanggung jawab pemenuhan kegiatan Tri Dharma Perguruan Tinggi.

2. Mengingat pelatihan menyusun dan mengimplementasikan laporan pajak UMKM ini sangat penting bagi para peserta pengelola usaha maka disarankan kegiatan ini dapat disosialiasikan dan berkelanjutan di daerah lainnya untuk mendukung 
program pemerintah untuk kegiatan pengabdian tentang hal-hal meningkatkan pemasukan pajak dalam baru dan ter-update, sehingga peserta negeri.

3. Pelaksana Pengabdian selanjutnya dapat lebih memahami perkembangan dapat lebih mengajarkan kepada peserta perpajakan.

\section{DAFTAR PUSTAKA}

Darwanto. 2013. Peningkatan Daya Saing UMKM Berbasis Inovasi dan Kreatifitas (Strategi Penguatan property right terhadap Inovasi dan Kreatifitas. Jurnal Bisnis dan Ekonomi, 20, 142-149.

Hejazziey, Djawahir. 2009. Pemberdayaan Koperasi, Usaha Mikro, Kecil dan Menengah (UMKM) Melalui Lembaga Keuangan Syariah (LKS) Untuk Mengentaskan Kemiskinan dan Pengurangan Pengangguran. Al-Iqtishad: Vol. I, No. 1, Januari.

Ikatan Akuntan Indonesia, 2016. Exposure Draft Standar Akuntansi Keuangan Entitas Mikro, Kecil, dan Menengah. Grha Akuntan, Jalan Sindanglaya No 1, Menteng, Jakarta 10310.

Jaya, I Made Laut Mertha dan Veronika Wiratna Sujarweni, 2019. Pengelolaan Keuangan Bumdes Sambimulyo di Kawasan Geoheritage "Tebing Breksi" Yogyakarta. Jurnal Padma Sri Kresna, Universitas Widya Mataram Yogyakarta, Vol. 1, No. 2.

Utami, Ai Annisaa dan Zahruddin, 2017. Voluntary Tax Compliance UMKM Kota Depok. SOSIO-E-KONS, Vol. 9 No. 3 Desember, hal. 175-181. 
Laporan dan Peraturan Perundang-undangan

Laporan Kinerja Kementrian Koperasi dan UKM Tahun 2016 (LAKIP KUKM 2016). Kementrian Koperasi dan Usaha Kecil dan Menengah Republik Indonesia.

Menristekdikti. 2016. Panduan Pelaksanaan Penelitian dan Pengabdian Masyarakat di Perguruan Tinggi Edisi X Tahun 2016. hlm. 4.

Pemerintah Nomor 46 Tahun 2013 tentang Pajak Penghasilan atas Penghasilan dari Usaha yang Diterima atau Diperoleh Wajib Pajak yang Memiliki Peredaran Bruto Tertentu (PP 46/2013).

Sumber pustaka on line:

CNN Indonesia, 2016, "Kontribusi UMKM Terhadap PDB Tembus Lebih Dari 60 Persen", Berita Bisnis. Diakses dari http://www.cnnindonesia.com. 